\title{
FACIES RELATIONSHIPS AND SEDIMENTATION IN LARGE RIFT LAKES AND IMPLICATIONS FOR HYDROCARBON EXPLORATION: EXAMPLES FROM LAKES TURKANA AND TANGANYIKA
}

\author{
ANDREW S. COHEN \\ Department of Geosciences, University of Arizona, Tucson, AZ 85721 (U.S.A.)
}

(Received January 25, 1988; accepted April 5, 1988)

\begin{abstract}
Cohen, A. S., 1989. Facies relationships and sedimentation in large rift lakes and implications for hydrocarbon exploration: examples from lakes Turkana and Tanganyika. Palaeogeogr., Palaeoclimatol., Palaeoecol., 70: $65-80$.

Two African lakes, Turkana and Tanganyika, illustrate a spectrum of sediments and facies architectures which can occur in large rift lacustrine basins. They demonstrate contrasts between sediments deposited in a semi-arid, moderately deep, mainly volcanic basin (Turkana) and a semi-humid, extremely deep basin without significant volcanism (Tanganyika).

Turkana deposits are dominated by rapidly accumulating, organic-poor, terrigenous muds. Coarse-clastic input is in part limited by ponding in marginal subbasins due to volcanic barriers. Profundal coarse-clastic deposition is rare. Sediments contain little biogenic components except in the sediment-starved south basin. Sediments are also poor in carbonates.

Tanganyika deposits are dominated by organic rich, biogenic muds. Steep fault-escarpments and uniform slopes along shelf platform and rift-axis lake margins promote the efficient transport of sands into profundal settings. Total clastic sediment supply into the basin is severely restricted by basin morphology with steep relief, backsloping, a limited drainage basin area and presettling in upstream Lake Kivu. Sediment ponding along margins is rare. Littoral carbonates are common; a consequence of low net clastic sedimentation rates.

Many of the differences between facies in the two lakes can be explained by contrasts in basin margin slope and relief, volcanic activity, and climate between the two lakes.

The results of this study suggest that lake deposits formed in Tanganyika-type rift basins are more appropriate exploration target for hydrocarbon exploration than those from Turkana-type basins.
\end{abstract}

\section{Introduction}

Depositional environments and processes in modern rift lakes provide useful analogues for the interpretation of ancient rift-lacustrine strata (Robbins, 1983; Bertani and Carozzi, 1984). Realistic facies architecture models of lake deposits can be useful in determining lacustrine vs. marine origins for unfossilifer- ous deposits (Winston et al., 1984), and assessing the hydrocarbon potential of particular, ancient rift-lake basins (Talbot, 1984). Studies of modern lake sediments in African Rift basins has shown that not all lakes are created equal in this regard (Frostick et al., 1986).

This paper examines the sedimentology and modern facies distribution patterns for two 
LAKE TANGANYIKA

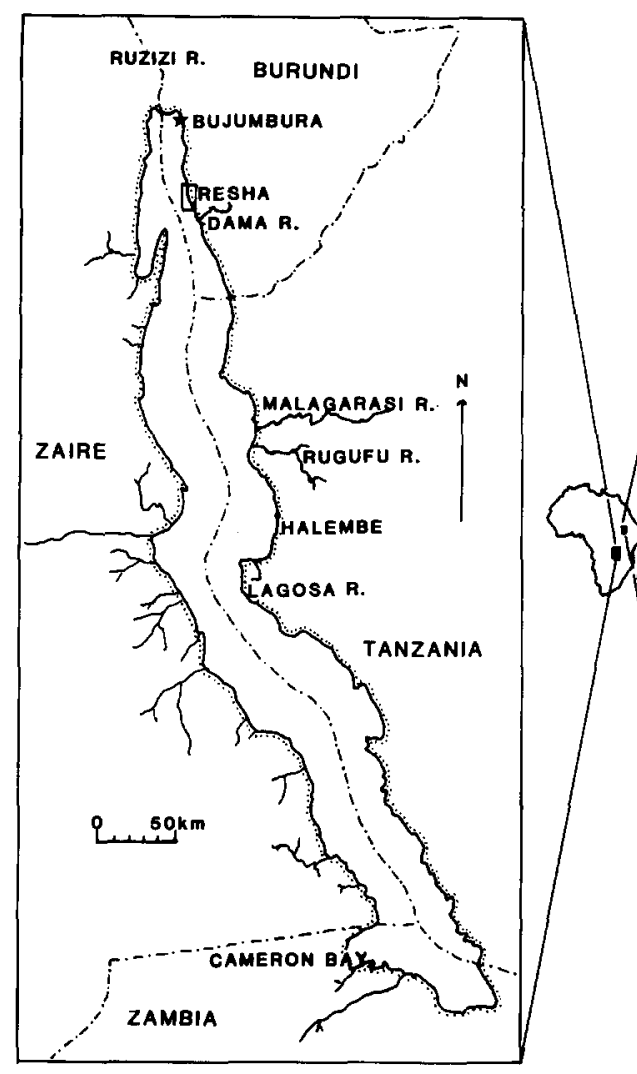

LAKE TURKANA

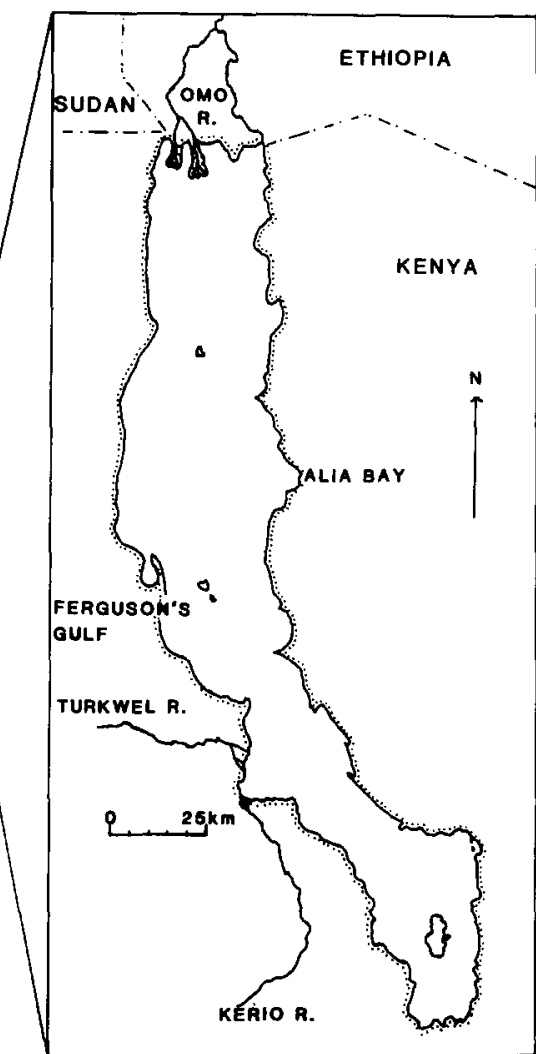

Fig.1. Location map for Lakes Turkana and Tanganyika and place names mentioned in text. The small inset box on the NE shore of Lake Tanganyika indicates the location of Fig.2.

large, African rift lakes, Turkana and Tanganyika (Fig.1). Both lakes have been studied in detail by numerous investigators over the past 20 years and provide a useful comparison of contrasting depositional styles and hydrocarbon potentials in large rift systems. Data include literature compilations and studies by the author (e.g. Cohen, 1984; Cohen et al., 1986; Cohen and Thouin, 1987), which involved field sampling, gravity and piston coring, Ekman dredge sampling and direct underwater observation sampling. Geophysical data from echo sounding bathymetric records and published high resolution seismic data are also available (Johnson, 1984; LeFournier et al., 1985; Rosendahl et al., 1986; Johnson et al., 1987; Rosendahl, 1987).

\section{Lake Turkana}

\section{Geological and limnological setting}

Lake Turkana ( $~ 7500 \mathrm{~km}^{2}, z_{\max } 116 \mathrm{~m}$ ) is the largest lake in the eastern branch of the African Rift System. It lies in a structurally complex rift setting in Northern Kenya and is presently the sump of a closed drainage basin. Turkana is surrounded by mixed, Precambrian granitic, metamorphic and late Tertiary-Quaternary volcanic terrains (plus subordinate Tertiary-Quaternary sediments).

The climate in the immediate vicinity of the lake is hot and semiarid, although the principal influent, the Omo River (accounting for almost $90 \%$ of the lake's river influent water 


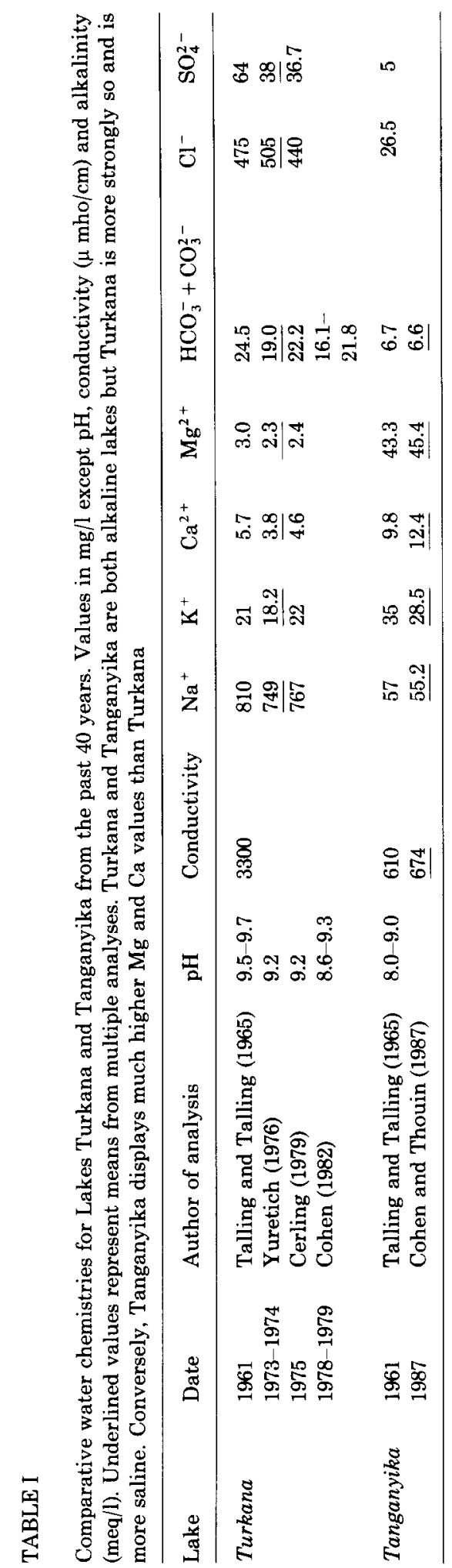


volume), drains the relatively moist southern Ethiopian highlands. The lake waters are moderately saline and alkaline (Table I), which strongly affects influent-flow suspended sediment distribution (Yuretich, 1979). Bottom waters of the lake are well oxygenated throughout both its north and south basins (Cohen, 1984).

Geological investigations of the lake's history were initially spurred by the important Plio-Pleistocene hominid discoveries in this region (e.g. Coppens et al., 1976). The late Quaternary depositional history of the lake has been studied by Butzer et al. (1972), Behrensmeyer (1974), Barton (1979), Cerling (1979), Owen et al. (1982), Dunkleman (1986), and Halfman (1987). Modern depositional processes have been documented by Butzer (1971), Yuretich (1976, 1979), Yuretich and Cerling (1983), Reid and Frostick (1985), Cohen et al. (1986), and Johnson et al. (1987).

\section{Sediment transport and accumulation}

Yuretich (1979) demonstrated the close relationship between fine clastic, profundal sediment composition and drainage basin lithology. The Omo River, draining predominantly Tertiary basalts, is the largest single source of fine clastics to the lake, dominating the depositional system of the lake's north basin. Halfman (1987) showed that basinal mud laminae, are generated on 4-yr cycles, perhaps as a consequence of El Niño/Southern Oscillation events. The coarse clastic load of the Omo River has been ponded in the proximal portions of the Omo Delta through much of the rivers Cenozoic history (Cohen et al., 1986). Reflection seismic data shows that during the Neogene, the lake's profundal sediments have been intruded by abundant, thick volcanic sequences (Dunkelman, 1986).

Very high net sediment accumulation rates have been recorded for the north basin. Barton (1979) reported rates for the central part of the north basin of $6 \mathrm{~mm} / \mathrm{yr}$, based upon a high resolution magnetic secular variation record.
Halfman (1987) and Johnson et al. (1987) recorded mean rates of 3-5 mm/yr based upon radiocarbon dates from piston cores. An extremely large drainage basin area: lake area (17.6:1), a limited Omo River floodplain area and limited vegetation cover all contribute to these high rates.

Other important quasi-perennial streams, the Turkwel and Kerio Rivers, empty into the south-central part of the lake. These rivers also yield little coarse clastic debris to the lake away from their proximal deltas, though old littoral sands, probably formed during a Late Pleistocene low-stand, are still exposed in some distal offshore regions.

The southern part of the lake is clasticsediment starved, relative to the north basin due to high relief basin margins on the west side which backshed clastics away from the lake, and extremely low runoff rates. Hence, surface sediment assemblages are dominated by ostracodal/diatomaceous silts and silty muds.

Cohen et al. (1986) described the coarse clastic sediments within Lake Turkana. Predominant mafic volcanic source terrains provide primarily mud and cobble sized materials to the basin, with little sand production. Sands and gravels are not presently carried into offshore regions of Lake Turkana. Where exposed Quaternary lacustrine sand belts are wide in an offshore direction (e.g. along the northeast margin of the lake) they are clearly time transgressive, the result of staircased strandline deposition (Frostick and Reid, 1987). The three major river influents, as well as numerous large seasonal streams with continuous subsurface discharge, are all choked by macrophytic vegetation in their proximal deltas. Sandy bedload has been trapped in subsiding marginal deltaic subbasins, many of which are now fault exposed along the north, northeast and northwest sides of the lake. Volcanic intumescence appears to be particularly effective in limiting the movement of coarse clastics into the lake. The small quantities of coarse clastics which do reach the Lake Turkana littoral, get there from smaller bed-load stream 
systems (ones which are not vegetation choked) and via colluvial rockfall, particularly along volcanic headlands. Offshore movement of wind-blown sand does not appear to be an important factor here.

Bedload stream delivered sands are dispersed in narrow, shoreline parallel bodies, which rarely exceed $1 \mathrm{~km}$ in width. The lateral extent to these sand bodies appears to be regulated by the presence of headland barriers, particularly along the lake's southern shorelines. Along the northwest margin of the lake, headland barriers are rare and long-shore sand belts are more continuous.

Headlands affect the plan-view geometry of sand bodies in two ways. First, they produce rapid distortions in the widths of the sand blanket, with extremely rapid pinchouts in the vicinity of the headland and an overall wedgeshaped sand body. Second, they result in the production of distinctive muddy gravels and rapid facies transitions in the immediate vicinity of the headlands.

Coarse clastic lithologies within the nearshore sand-belts are heterogeneous, depending on provenance, alkalinity-induced corrosion and wave reworking. Basaltic headlands yield bimodal and polymodal pebbly muds. Small drainages from metamorphic sources deliver abundant feldspathic sands to the lake. These sands mature compositionally over extremely short distances due to feldspar corrosion, and their lithification would yield quartz arenites in some cases. They retain characteristically angular-subangular textures however, indicative of their brief transport histories and firstcycle origins. Along shorelines which are not influenced by volcanic headlands transport distances are greater. In those areas increased textural maturity occurs in sands in down-flow longshore current direction if those currents are consistently directed year-round (e.g. Ferguson's Gulf). More typically, longshore current directionality is highly seasonal, and no clear textural maturity patterns are observed.

Offshore transport of coarse clastic sediment in Lake Turkana in sublacustrine canyon systems is negligible, even along the steepbanked south basin. Sand fraction bottom water gravity transport does not appear to be an important process in offshore sediment delivery, as fine grained turbidites are quite rare in Turkana basinal sediments. In part this can be attributed to low nearshore bathymetric gradients. Between the shoreline and $5 \mathrm{~km}$ offshore (measured normal to local shoreline orientation) the mean bottom gradient for the entire lake is $0.6 \pm 0.4 \%$. Although density flows do occur off seasonal stream deltas during flash floods (L. Frostick, pers. comm., 1988) their ability to transport sands great distances appears to be limited. Terrigenous sands almost never occur in surficial sediment samples more than $5 \mathrm{~km}$ offshore (Yuretich, 1976; Cohen, 1982). Carbonate deposition in Lake Turkana is presently dominated by sublittoral to profundal, authigenic low-Mg micrite and ostracodal sands and silts (Halfman, 1987). The South Basin is the major locus for such deposits but they are also known from the North Basin. Gastropods are rare and bivalves absent in the modern lake due to alkalinity constraints, though reworked molluscan shells lags (from Holocene terraces) occur locally in the shallow littoral. Other forms of littoral-sublittoral carbonates, such as ooid shoals and bivalve or algal bioherms, are inhibited in the modern lake by both high littoral suspended sediment loads and low $\mathrm{Ca}^{2+}$ availability. In contrast, higher lake stands during the Early Pleistocene and again in the Early Holocene saw periods of abundant lime grainstone, boundstone and framestone deposition, possibly a consequence of lowered turbidity (Abell et al., 1982; Schwartz, 1981).

Basinal muds are composed of montmorillonite $>>$ kaolinite + illite $>$ calcite. Biogenic calcite and silica are most important in the south basin, but total organic carbon contents are low, averaging less than 1\% (Yuretich, 1979). Basinal mud laminae are preserved despite high oxygen content in the profundal zone, because low organic detritus availability inhibits infaunal bioturbation. 


\section{Lake Tanganyika}

\section{Geological and limnological setting}

Lake Tanganyika $\left(32,600 \mathrm{~km}^{2}, z_{\max } 1470 \mathrm{~m}\right)$ is the largest lake in the western branch of the African Rift System. It occupies a series of linked, axial-rift, half-graben basins, all of which have considerable structural and topographic relief (Rosendahl et al., 1986). The lake drains variable-grade, Precambrian metasediments and granitic rocks in its immediate vicinity, which yield abundant arkosic sands. Minor Late Tertiary-Quaternary volcanics also occur within the drainage, in the Kivu Basin. The semi-humid Lake Tanganyika Basin receives between $850-1700 \mathrm{~mm}$ of precipitation per year. The lake is externally drained, though the overwhelming majority of water loss occurs through evapotranspiration. Two major rivers and numerous smaller perennial ones feed the lake. The Ruzizi River, an axial rift stream, drains the upper Ruzizi Basin and Lake Kivu to the north. The Malagarasi River enters the lake along the east-central side on a rift-platform ramp (sensu Rosendahl, 1987), and drains portions of Western Tanzania and Burundi outside of the rift. Almost all other drainage into the lake head within the structural basins forming the Tanganyikan segment of the Western Rift.

Tanganyikan lake water is considerably less saline and alkaline than Turkana. Tanganyika's high $\mathrm{Mg}$ and $\mathrm{Ca}$ concentrations and its high $\mathrm{Mg} / \mathrm{Ca}$ ratio (Table I), also differentiates the two lakes. As a consequence of Tanganyika's relatively low surface water density, all influents analyzed to date except the Malagarasi enter the lake as relatively coherent underflows, generated by chemical contrasts in the Ruzizi River or thermal contrasts for all other streams (Wombwell, 1986). Bottom waters are anoxic below $150-250 \mathrm{~m}$.

The geological history of the basin is poorly known, due to a paucity of outcrop exposure and radiometrically dateable rocks. Plio-Pleistocene, fluviolacustrine sediments of the Ruzizi Plain have been investigated most recently by
Chorowicz and Thouin (1985), and Ebinger (1988). Late Quaternary-Holocene sedimentation within the lake was studied by Living stone (1965), Degens et al. (1971), Hecky and Degens (1973), Hecky (1978), Mondeguer (1984), and Haberyan and Hecky (1987). Reflection seismic profiling by Project PROBE (Rosendahl and Livingstone, 1983; Rosendahl et al., 1986; Rosendahl, 1987; Scholz and Rosendahl, 1987) has illustrated the major tectono-sedimentary elements of the Tanganyikan depositional basins, which have been placed in a riftevolutionary context by LeFournier et al. (1985).

\section{Sediment transport and accumulation}

Holocene, profundal sedimentation in Lake Tanganyika is dominated by laminated, organic rich, diatomaceous silts (Degens et al., 1971). Subordinate clays (primarily kaolinite with lesser amounts of chlorite, and illite) and carbonates (calcite and aragonite) also form laminae. Sediment accumulation rates of basinal muds in Tanganyika are approximately $0.4-0.5 \mathrm{~mm} / \mathrm{yr}$, and are an order of magnitude lower on basinal sills.

Even the higher rates are considerably lower than those observed in Turkana, in part a consequence of both the much lower drainage basin area: lake area ratio (5.8:1, excluding the currently ponded Kivu Basin) and greater sediment stabilization due to plant cover in Tanganyika. Organic carbon content in profundal muds is high, ranging between 1-13 weight percent (Hecky and Degens, 1973).

Thick, poorly sorted, silt-sand turbidites are commonly interbedded within Tanganyikan basinal muds (Hecky and Degens, 1973; LeFournier et al., 1985; J. LeFournier, pers comm., 1986). Better sorted, sandy contourites, extending over many kilometers, also occur at profundal depths (Rosendahl and Livingstone, 1983; this study). Although the precise geographic provenance of these clean sands is unknown, their relationship with the density underflows discussed earlier seems likely by analogy with the documented origin of con- 
tourites in marine environments (Stow and Lovell, 1979; Stow, 1985).

The steep topography of most of the lake margin ensures that the upper profundal-sublittoral transition zone is narrow except along platform ramps. Bathymetric gradients in Lake Tanganyika average $8.5 \pm 9.7 \%$ slope between the shoreline and $5 \mathrm{~km}$ offshore. Recent, upper profundal deposits in Lake Tanganyika are much more heterogeneous than in Lake Turkana. Greenish-grey to black, laminated and massive fossiliferous muds are the most common sediment at depths between $50-150 \mathrm{~m}$. Sands and silty sands found at these depths are of two major classes. Poorly sorted, terrigenous sands form extensive elongate bodies perpendicular to the shoreline. These sands are most common along steeply sloping bottoms, where they are forming as channelized sublacustrine canyon turbidites and unconfined, cascading grain flows below cliff faces. Tabular, mixed carbonate-terrigenous sands occur on platform ramps and in distal deltaic environments. These poorly sorted, thin bedded sands appear to have irregular shapes in plan view.

Extremely small (less than $1 \mathrm{~km}^{2}$ ) fan deltas occur commonly along the major boundary faults, with outlet spacings on the order of $10 \mathrm{~km}$. Like other rift escarpment systems (Blair, 1987) their feeder streams drain relatively small, high relief basins, accounting for the limited quantity of sediment delivered to their deltas. High offshore relief restricts the progradation of these fan deltas and they grade rapidly into offshore channelized turbidites and grain flows. Texturally, the fans consist of poorly sorted, massive, terrigenous sands and sandy conglomerates. These pass laterally into very coarse grained, clast supported, subangular conglomerates where colluvial rockfall influence on sedimentation begins to exceed fluvial input. Offshore fans pass abruptly and over short distances into profundal muds, although depths may exceed several hundred meters. Along individual escarpments the facies pattern observed bears striking similarities to that described by Link and
Osborne (1978) for the rapid, fault controlled, Violin Breccia-Peace Valley Beds transition of the Pliocene Ridge Basin Group in California, although the tectonic settings of the two lake basins are quite dissimilar.

Where streams enter the lake along fault block axes, drainage basin areas are larger and the quantity of sand supplied to the littoral zone increases. This phenomenon is exemplified in the outlets of the Ruzizi River at the north end of the lake, the Dama River near Rumonge, Burundi, and the Lagosa River in Central West Tanzania. At all of these deltas, offshore, coarse clastic progradation is more significant than along boundary fault shorelines, as evidenced by bathymetric profiling and offshore coring. Further, the quantities of sand delivered to the lake in these areas is sufficient to generate significant littoral longshore drift deposition, with the formation of extensive planar stratified and low angle tabular, cross stratified, well sorted beach and bar deposits.

\section{Carbonate sedimentation}

Lake Tanganyika differs considerably from Turkana in degree and variety of littoral-sublittoral carbonate sedimentation (Cohen and Gevirtzman, 1986; Cohen and Thouin, 1987). This in large part can be attributed to the limited clastic inflow to the lake, due to short lateral drainages and upstream clastic ponding in Lake Kivu. The inverse relationship between local clastic input and lime mud/sand/ boundstone deposits is well illustrated by the local geographic distribution of each in the area near Resha, Burundi (Fig.2). Littoral sediments around the mouths of the small tributaries are uniformly uncemented sands and silty sands. Beachrock cementation of terrigenous sands is restricted to areas more than $150 \mathrm{~m}$ from perennial inflow sites. The occurrence of carbonate coated grains (oolitic shoals and oncolites) is even more restricted. These sediments form only along shoreline more than $700 \mathrm{~m}$ from a perennial stream outflow. Carbonate, microbial bioherms are 


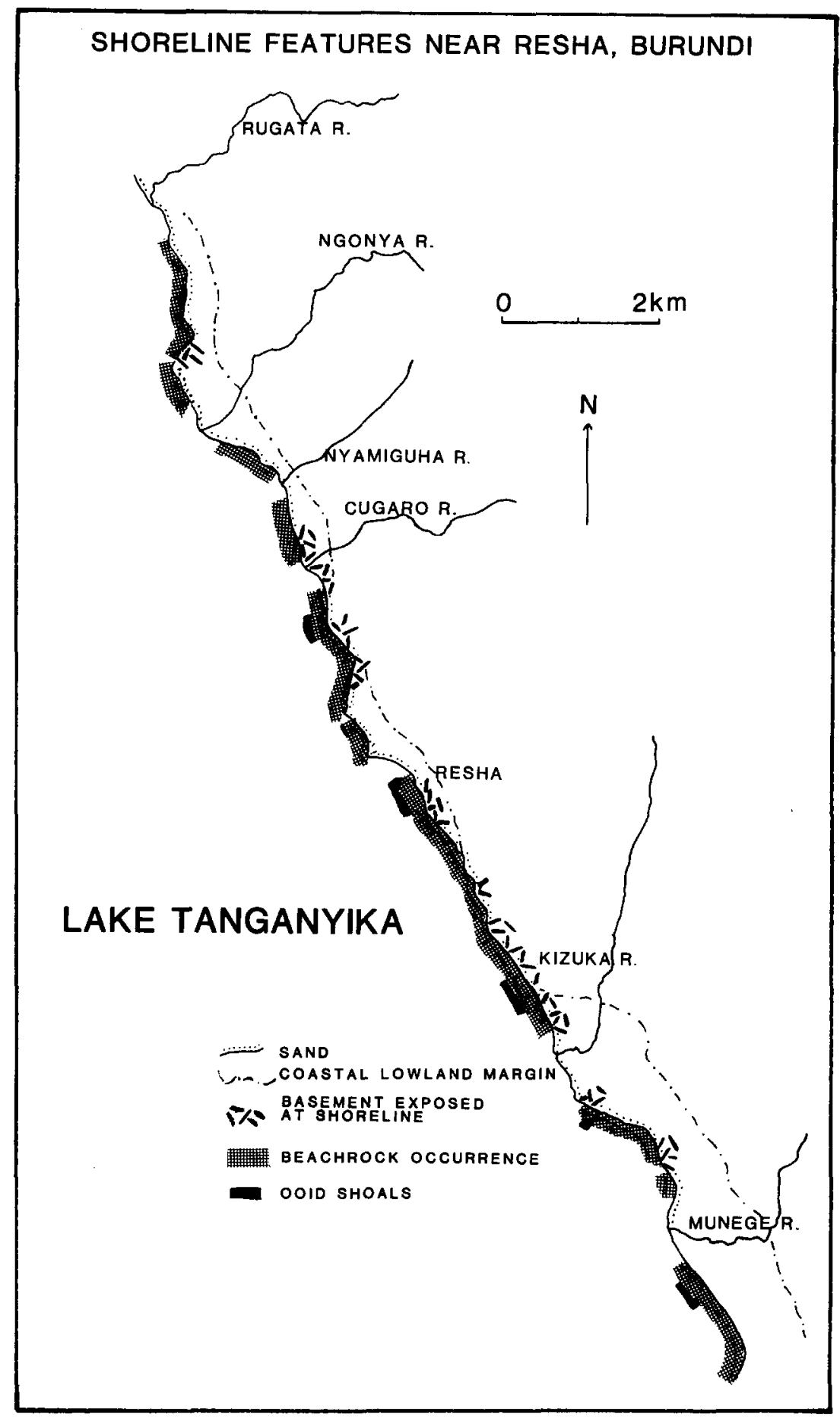

Fig.2. Shoreline facies distribution map for the area around Resha, Burundi (see inset location on Fig.1). Carbonate sediments (both beachrock and ooid shọals) appear to be strongly inhibited from areas around discharge points of perennial streams. All perennial streams within the map area are indicated. 
most numerous along sediment starved, high relief, boundary fault shorelines, where the settling of fine clastics is inhibited. Extensive (up to $100 \mathrm{~km}^{2}$ ) tabular gastropodal sands and their lithified equivalents which occur north and south of the Malagarasi Delta in Tanzania, south of Halembe, Tanzania and in Cameron Bay, Zambia, appear to represent sublittoral platform and rift block reaches which are currently bypassed by clastic sediment pathways. Shell hashes may represent lowered lake level winnowing events when net clastic sedimentation in these areas was actually negative (Cohen, 1987).

\section{Contrasts in facies architecture between the two lakes and implications for other rift lake systems}

Lakes Turkana and Tanganyika share many important structural similarities which affect the distribution of sediments in the two lakes (Frostick and Reid, 1987). However, important differences in sedimentation and stratal geometry exist between the two lakes (see Fig.4, Table II). These differences are ultimately a function of climatic and lithologic contrasts between the two basins.

Contrasts in basinal facies geometry and lithology

Depositional environments and therefore the composition of the profundal muds differs

\section{TABLE II}

Summary of major contrasts between depositional processes, sedimentation and facies relationships for Lakes Turkana and Tanganyika

TURKANA

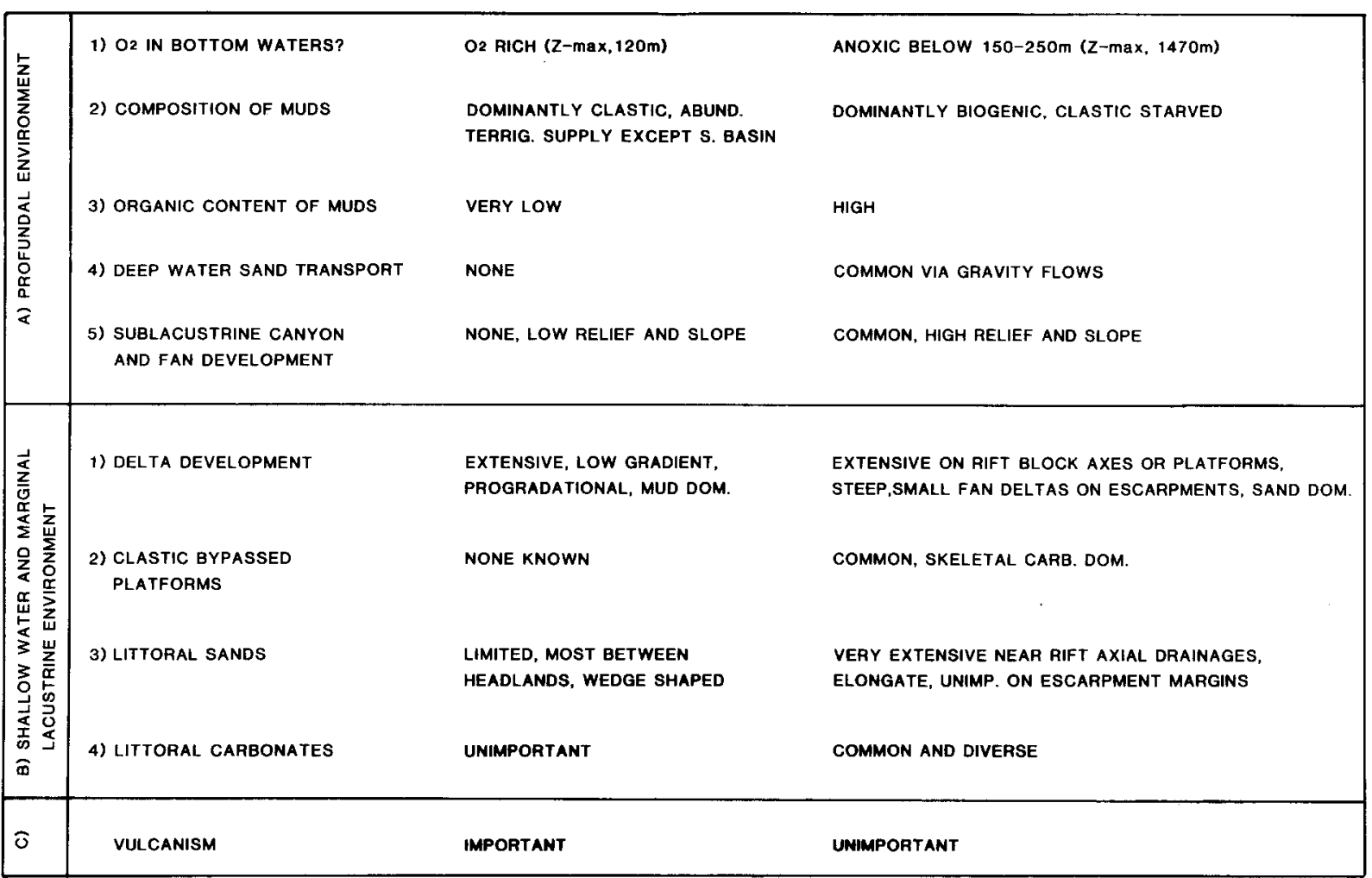




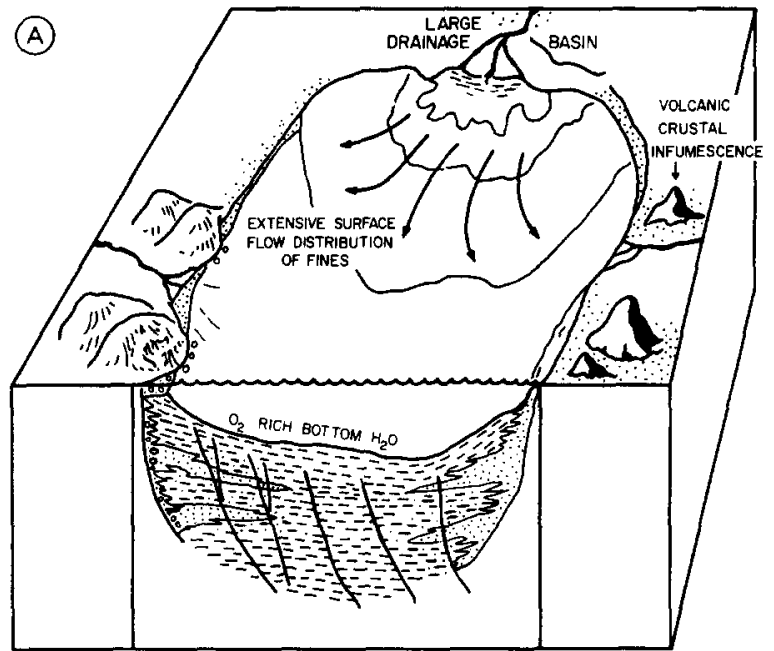

TURKANA TYPE BASIN- PROCESS

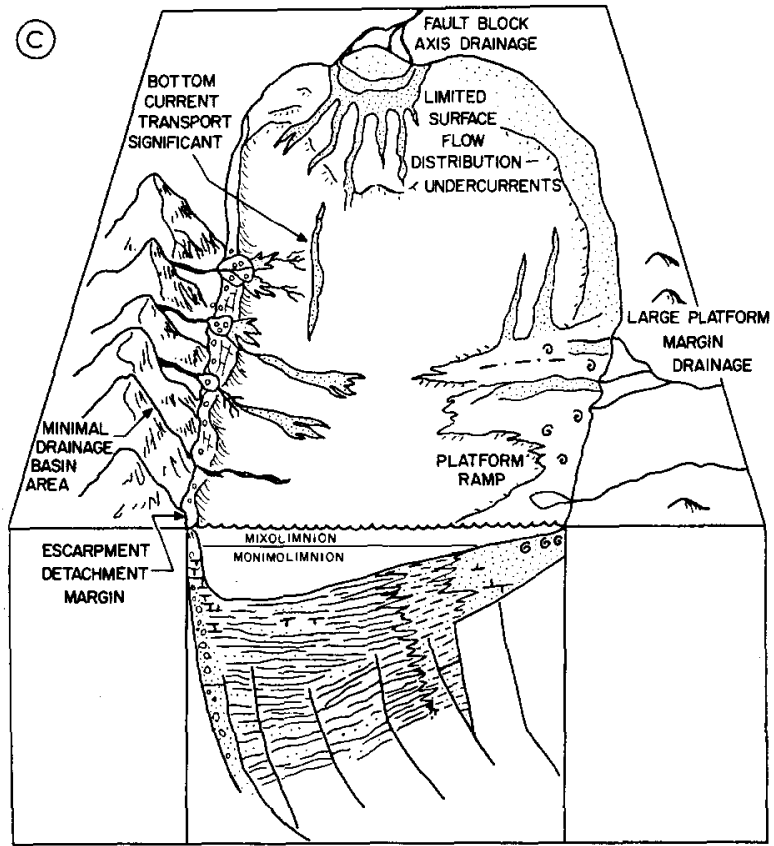

TANGANYIKA TYPE BASIN- PROCESS

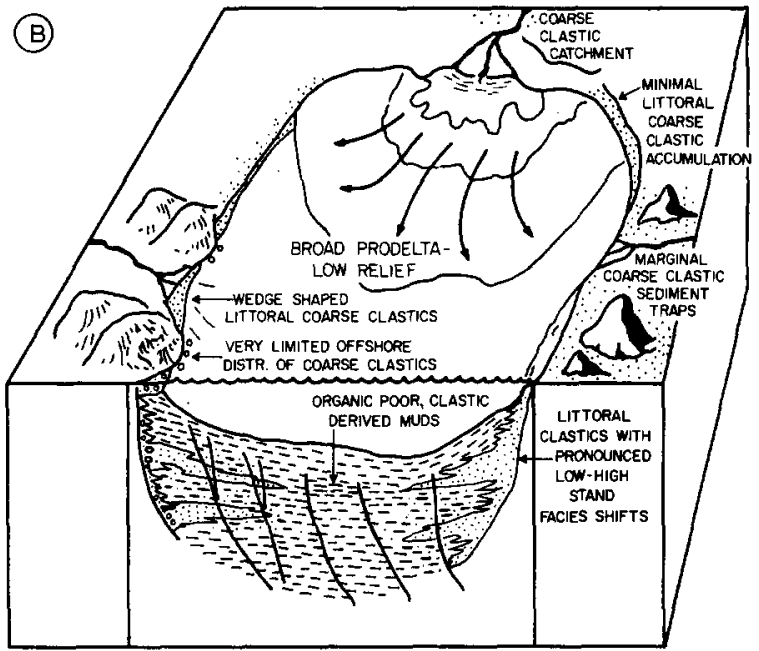

TURKANA TYPE BASIN- PRODUCT

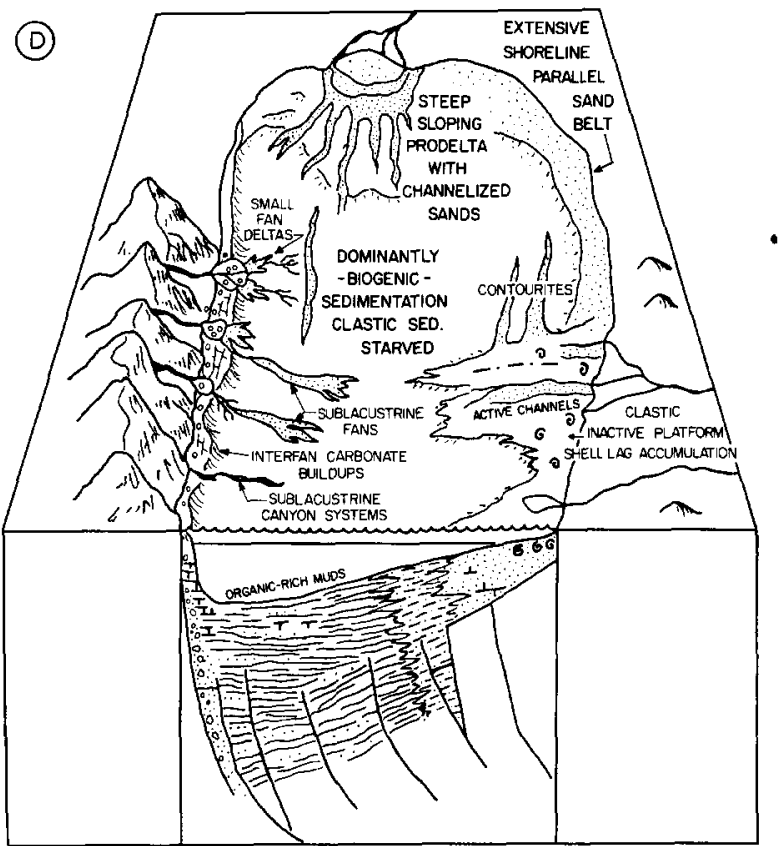

TANGANYIKA TYPE BASIN - PRODUCT

Fig.3. Process (A,C)-product (B,D) models for sedimentation in Lakes Turkana and Tanganyika. A,B. Turkanan sedimentation is predominantly detrital and occurs at all depths under strongly oxidizing conditions. Low slope and internal drainage combine to cause extreme lateral facies shifts during lake-level fluctuations, introducing alluvial plain-lake margin sand sheets into the basin center during low lake stands. Littoral sands wedge out due to volcanic headland barriers. Minimal sand discharge to the central basin occurs at high lake stands due to coarse clastic ponding by volcanic piles and crustal intumescence. C,D. Tanganyikan sedimentation is more heterogeneous. The profundal zone is mostly monimolimnetic and the drainage basin is relatively small and steep-sided, thus profundal muds are organic-rich and largely biogenic (clastic sediment starved). Littoral sands are deposited over extensive regions of the littoral and sublittoral zones on rift axes and platform ramps but are very limited along escarpment margins. Littoral carbonate sedimentation occurs on clastic starved escarpment margins and clastic bypassed portions of platforms. Deep water, sand deposition occurs via sublacustrine canyon-fan systems with probable contourite reworking.

Illustrations are composites of features found in many areas and do not represent single regions of each lake. 
radically between the two lakes. Lake Turkana is shallow and well oxygenated to the bottom due to its high wind run/depth ratio. Its basinal muds have low organic carbon content due to oxygenation and high clastic accumulation rates. Suspended muds are transported long distances off delta fronts due to the strong density contrasts between fresh influent and moderately saline lake waters. A large drainage area/lake area ratio and relatively small surrounding alluvial floodplains ensure that profundal sediment accumulation rates of detrital clays are high in the north basin. These rates are lower in the south basin where sediment starvation results from more limited source terrain (due to steeper rift escarpments). Here sediments are dominantly biogenic.

By contrast, Tanganyikan bottom waters are strongly reducing and the subsequent anoxia over most of the lake's floor has allowed the accumulation of significant quantities of autochthonous organic carbon. Detrital sediment accumulation rates are significantly lower than in Turkana, in large part due to the lake's much smaller unponded drainage basin area/ lake area ratio. Degens et al. (1971, p. 233) showed that in surface sediments from profundal depths "the fine-grained basinal sediments are almost entirely composed of the skeletal remains of diatoms and organic matter". Most suspended muds entering the lake are dispersed through underflows since density contrasts between lake and river waters are primarily mediated by temperature differences (cold denser influent vs. warm, lighter lake water), rather than by salinity differences. As a consequence Tanganyikan deltas tend to be quite steep fronted, even in axial rift block drainages. Such oversteepening is almost certainly responsible for producing many of the turbidites observed on Tanganyikan prodelta slopes (Degens et al., 1971, cf. Crossley, 1984, in Lake Malawi).

The delivery of coarse clastic sediments into the central basins is radically different between the two lakes. Differences in basinal slope and relief between Turkana (gentle) and
Tanganyika (steep) have lead to much greater geographic partitioning of coarse and fine grained clastics in the former lake. In Turkana, an absence of appropriate parent material, marginal basin and volcanic edifice ponding, and low basinal slopes all insure that little sand or gravel is introduced into the profundal environment. In contrast, deep water and offshore, coarse clastic sedimentation is a common phenomenon in Tanganyika. Platform ramps and rift block axes provide the major access to profundal environments for sand sheets derived from the larger river systems such as the Ruzizi, Malagarasi and Rugufu. Due to consequent drainages which backshed water and sediments away from the rift, the boundary escarpments of Tanganyika provide limited source areas and hence, minimal amounts of coarse clastics to the deep-water portions of the lake.

Unlike Turkana, deep water sands in Tanganyika appear to be extensively reworked by turbidity and contour currents. The latter in particular are probably responsible for producing the relatively well sorted, deep-water, fine sands found in some cores. Le Fournier et al. (1985 and pers. comm., 1986) have shown that large sandy turbidites and shoestring sands extend into Lake Tanganyika for great distances (tens of km's). Sandy contourites have been observed in both Lakes Tanganyika and Malawi (but not Turkana), interbedded with or occurring lateral to profundal muds (Rosendahl and Livingstone, 1983; Johnson, 1984).

Marginal basin ponding of sands from offshore movement is less important around Tanganyika than around Turkana. The Ruzizi Plain at the north end of Lake Tanganyika appears to be the only major marginal sediment trap active in the post-Miocene lake basin (Chorowicz and Thouin, 1985), in contrast to Lake Turkana, where numerous marginal basins have developed since the early Pliocene (Cohen, 1981). Unlike Turkana, Tanganyika has experienced almost no vulcanism within the immediate vicinity of the lake. Ponding of sediments by volcanic intumescence and surficial flows is important in 
Turkana (Truckle, 1976; Cohen et al., 1986; Watkins, 1986), but not in Tanganyika.

Large stratal thickness/lateral width ratios are characteristic of rift lake profundal sediments as a consequence of prolonged, rapid subsidence. Le Fournier (1980) and Le Fournier et al. (1985) have shown that thick (up to several $1000 \mathrm{~m}$ ), wedge shaped accumulations of organic rich muds are characteristic features of the later stages of rift lake evolution. Where climatic conditions and/or runoff conditions are appropriate for deep lakes to develop, as in Tanganyika, the probability of meromixis is enhanced by high subsidence/sedimentation ratios. Shallow basins like Turkana, formed in more arid climates, or experiencing higher sedimentation rates, are less likely to experience prolonged anoxia and accumulate thick sequences of organic rich sediments.

Rapid, rift margin subsidence has produced wedge shaped, ponded organic-rich mud sequences in Tanganyika, which are best documented in the Rumonge Basin (Le Fournier et al., 1985). Similar goemetries are known from seismic evidence elsewhere in both Lakes Tanganyika and Malawi (Ebinger et al., 1984; Rosendahl et al., 1986). Thick, ponded organic mud wedges, with interbedded clean sands are predicted to occur down the length of large rift lakes like Tanganyika or Malawi. These wedges will display alternate facing due to the alternation of half-graben boundary faults across accommodation zones (Le Fournier, 1980; Johnson, 1984; Rosendahl et al., 1986). Because of their structural similarities, wedgelike profundal mud basin fills would occur in Turkana type rift basins as well. However, they would lack the high organic concentrations and intercalated profundal sands.

\section{Contrasts in littoral facies geometry and lithology}

A consequence of Turkana's low average basinal slope and closed basin configuration is that small lake level fluctuations produce large shifts in lake margin facies. Thin sand sheets quickly migrate basinwards during low lake stands (Frostick and Reid, 1987). Average seasonal lake level fluctuations of $0.5-1.0 \mathrm{~m}$ produce a mean shoreline migration of $85-170 \mathrm{~m}$. A longer term drop of $20 \mathrm{~m}$ between the late 19th and mid 20th century, resulted in a mean shoreface regression of over $3 \mathrm{~km}$ (Fig.4). Facies migration due to changes in lake level are more constrained in Tanganyika, because its coincident margin (sensu Donovan, 1975) results in a high mean, basin-margin slope. Seasonal lake level fluctuations during the past 40 years account for between $3-16 \mathrm{~m}$ of shoreline migration annually, and the $11.5 \mathrm{~m}$ lake level decline in Lake Tanganyika between 1878-1893 resulted in a mean, shoreline migration of only $120 \mathrm{~m}$ lakewards (Evert, 1980). Given these steep average slopes, large scale, littoral facies progradation in Tanganyika is limited to platform ramps and basin axis margins, as in Lake Malawi (Crossley, 1984).

Finally, differences in coastline relief have produced remarkably different littoral facies assemblages in the two lakes. In Turkana, basaltic source rock lithology, noncoincident margins with low gradients, hypopycnal inflow of the Omo River and volcanic sediment transport barriers all promote widespread and abundant littoral mud deposition. Littoral sand deposition is limited under these conditions. In the high relief southern basin clastic sedimentation rates are lower and littoral sands are proportionately richer in biogenic debris, particularly ostracode valves and diatom frustules. Even in the South Basin however, coated grain, cement and boundstone deposition is inhibited. Low $\mathrm{Ca}^{2+}$ concentrations in highly alkaline waters, high turbidity and high clastic sedimentation rates all limit the accumulation of littoral carbonates throughout the lake.

Littoral zones of Tanganyika display a different set of facies. Along platform and riftblock axis coastlines, elongate sand bodies (bar-shoreface-dune complexes), often extending for over $20 \mathrm{~km}$, reflect the absence of significant barriers to sediment transport. Since most influents behave as undercurrents 
LAKE LEVEL FLUCTUATIONS

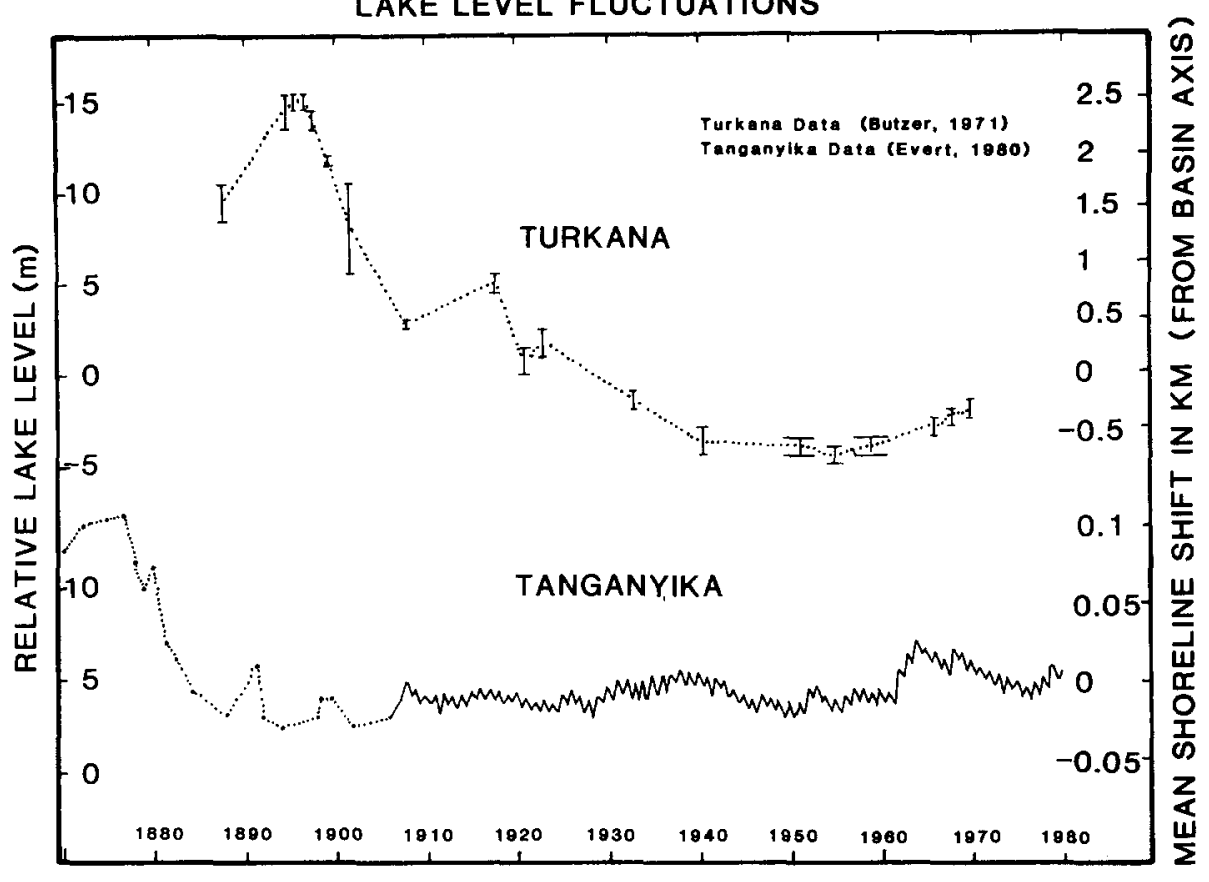

Fig.4. Historic lake level fluctuations and their effects on mean shoreline positions in Turkana and Tanganyika. Short term level fluctuations in Turkana are greater than in Tanganyika but these translate into order of magnitude larger shoreline positional shifts for Turkana due to its low bottom gradient.

upon reaching the lake, littoral turbidity and shoreface mud deposition are much lower than in Lake Turkana. Consequently, most Tanganyikan littoral sands are texturally mature. Their maturity is also enhanced by provenance lithologies (an absence of mafic volcanics and an abundance of granitic rocks), enhanced onshore wave and longshore drift activity, and intralacustrine feldspar corrosion (Cohen and Thouin, 1987).

Along high relief detachment-boundary escarpments, stream influents are small and highly localized, causing clastic sediment starvation. Such small coastal fan deltas display very rapid lateral fining outwards but have coarse channel fill. This restriction and channelization of clastic sediments is the most important factor allowing the deposition of relatively pure carbonates along segments of escarpment coastlines.

\section{Deep rift lake facies relationships: implications for source and reservoir rock continuity}

Both Lakes Turkana and Tanganyika have been the foci of intense geological exploration with one goal being an understanding of the origin and structure of rift-lacustrine hydrocarbon fields. Several features make the Tanganyika model a more realistic model target for hydrocarbon exploration than Turkana.

The predominance of thick sequences of organic rich muds, deposited in stratigraphic continuity with basinal sands, is perhaps the most important feature which sets Tanganyikan sediments apart from those of Turkana. Deep water, biogenic sediments appear to reach their greatest thicknesses where focused on the down-dip sides of asymmetrical halfgraben basins. Rosendahl et al. (1986) have 
documented up to $3000 \mathrm{~m}$ of sediments deposited along Tanganyikan escarpment margins, much of which is likely to be organic-carbon rich. Surface sediment sampling suggests that these muds contain frequent thin, shoestring sands, some of which are initially delivered down escarpment slopes via sublacustrine canyon-fan systems and reworked as contourites. Therefore, many of them are likely to possess high inter-particle porosity. If, as seems likely, underflows in Lake Tanganyika are capable of reworking sediments over considerable distances, then platform margin derived sands must also be considered as potential reservoir sands. Platform sands are volumetrically more important for the lake's sand budget than the localized escarpment sands. However, they normally derive from the side opposite the organic mud depocenters (unlike the escarpment sands). Determining the relative contribution of these two distinct sand sources to profundal reservoir sand bodies will be an important area of future research.

Modern Lake Turkana muds are clastic rich and organic poor. Pre-late Holocene sediments, deposited during both deep and extremely shallow lake stands and under conditions of lower clastic sediment accumulation rates may have been organic rich, like volcanic rift Lakes Kivu and Bogoria (Hecky and Degens, 1973; Tiercelin et al., 1980). However, vast intrabasinal volcanic deposits make the accumulation of thick sequences of organic muds less likely than in Tanganyika. Further, the partitioning of the Lake Turkana depositional basins by volcanic flows, cones and crustal intumescence has limited sand delivery to the central mud depocenters limited by eliminating the continuous basin-sloping ramps common to Tanganyika. The volcanically active and semi-arid Gregory and Rio Grande Rifts both show low probabilities of significant hydrocarbon potential. Conversely, Cretaceous Brazilian Rift Basins (Ojeda, 1982), the North Sea, the Central African Rift and the Western Rift (Bosworth et al., 1986) are all rift systems where volcanics are subordinate and are all important or potentially important petroleum producing regions. Whereas marginal PlioPleistocene sub-basins dominated by sands are common around the periphery of Lake Turkana they are nearly absent around Tanganyika (the rift axial Ruzizi Plain being the sole important exception). Thus, even during high lake stands, when anoxic muds may have accumulated in the central Turkana Basin, deep water sand deposition would have been uncommon.

Limestones in depositional and fault contact with basinal muds in Lake Tanganyika provide a secondary focus of interest for rift-lacustrine hydrocarbon research. Tanganyikan skeletal carbonates (on clastic-bypassed ramps) and microbial bioherms are both fringed on their offshore margins by deep-water muds.

The two provide radically different potential exploration models. Skeletal ramp carbonates are probably tabular bodies of great lateral extent (both alongshore and offshore). Bioherms seem to be concentrated along fault escarpments as linear and often disconnected mounds (Cohen and Thouin, 1987). These two lithologies are similar in their apparently high primary porosity and proximity to potential basin mud reservoirs.

In Turkana, carbonate deposition is inhibited today by high rates of volcanic-derived mud influx and low calcium availability. Fossil evidence indicates that lake margin carbonate deposition during Turkana high stands was significantly higher than at present (Abell et al., 1982). However, these littoral carbonates do not appear in depositional or fault contact with organic rich muds.

Lakes Turkana and Tanganyika are useful analogues for understanding part of the spectrum of depositional styles found in rift lake strata. The two lakes are structurally similar, yet differ sedimentologically due to radical differences of volcanic activity, basin relief, lake level, and climate. Careful attention must be paid to all of these variables in the construction of realistic facies models for ancient rift lakes. 


\section{Acknowledgements}

I thank W. R. Dickinson, K. Kelts, M. R. Talbot, L. E. Frostick and L. Anovitz for their comments and suggestions on this paper.

Research on Lakes Turkana and Tanganyika was conducted under the auspices of the National Museums of Kenya, The University of Burundi and the National Research Council of Tanzania. Funding was provided by NSF Grants EAR 77-2349 and BSR 8415289.

\section{References}

Abell, P., Awramwik, S., Osborne, R. and Tomellini, S., 1982. Plio-Pleistocene lacustrine stromatolites from Lake Turkana, Kenya: Morphology, stratigraphy and stable isotopes. Sediment. Geol., 32: 1-26.

Barton, C. E., 1979. Paleomagnetic studies of East African lake sediments - First progress report. Univ. Edinburgh, Geophys. Dep. Rep., 23 pp.

Behrensmeyer, A. K., 1974. Late Cenozoic sedimentation in the Lake Rudolf Basin. Ann. Geol. Surv. Egypt, 4: 287-306.

Bertani, R. T. and Carozzi, A. V., 1984. Microfacies, depositional models and diagenesis of the Lagoa Feia Formation (Lower Cretaceous) Campos Basin. Petrobras Cienc. Tec. Pet., 14, 104 pp.

Blair, T., 1987. Tectonic and hydrologic controls on cyclic alluvial fan, fluvial, and lacustrine rift-basin sedimentation, Jurassic-Lowermost Cretaceous Todos Santos Formation, Chiapas, Mexico. J. Sediment. Petrol., 57: 845-862.

Bosworth, W., Lambiase, J. and Keisler, R., 1986. A new look at Gregory's Rift: The structural style of continental rifting. EOS, 67: 577, 582-583.

Butzer, K., 1971. Recent history of an Ethiopian delta. Univ. Chicago Dep. Geogr. Res. Pap., 136, 184 pp.

Butzer, K., Isaac, G., Richardson, J. and WashbournKamau, C., 1972. Radiocarbon dating of East African lake levels. Science, 175: 1069-1076.

Cerling, T., 1979. Paleochemistry of Plio-Pleistocene Lake Turkana, Kenya. Palaeogeogr. Palaeoclimatol., Palaeoecol., 27: 247-286.

Chorowicz, J. and Thouin, C., 1985. Failles synsedimentaires et structure de la plaine de la Rusizi. C. R. Acad. Sci. Paris, 301: 835-840.

Cohen, A., 1981. Paleolimnological research at Lake Turkana, Kenya. Paleoecol. Afr. 13: 61-82.

Cohen, A., 1982. Ecological and paleoecological aspects of the rift lakes of East Africa. Thesis. Univ. California, Davis, 314 pp.

Cohen, A., 1984. Effect of zoobenthic standing crop on laminae preservation in tropical lake sediment, Lake Turkana, Kenya. J. Paleontol., 58: 499-510.

Cohen, A., 1987. Skeletal accumulations and the taphonomy of lacustrine coquinites: evidence from modern lakes. In: Geol. Soc. Am., Rocky Mountain Sect. Annu. Meet., Boulder, Colo., Abstr, with Programs, p. 267.

Cohen, A. and Gevirtzman, D., 1986. Littoral carbonate sedimentation in modern Lake Tanganyika, Africa. In: Geol. Soc. Am., Natl. Meet., San Antonio, Tex., Abstr. with Programs, 18: 568.

Cohen, A. and Thouin, C., 1987. Nearshore carbonate deposits in Lake Tanganyika. Geology, 15: 414-418.

Cohen, A., Ferguson, D., Gram, P., Hubler, S. and Sims, K. W., 1986. The distribution of coarse-grained sediments in modern Lake Turkana, Kenya: implications for clastic sedimentation models of rift lakes. In: L. Frostick et al. (Editors), Sedimentation in the African Rifts. Geol. Soc. London Spec. Publ., 25: 127-139.

Coppens, Y., Howell, F. C., Isaac, G. and Leakey, R., 1976. Earliest man and environments in the Lake Rudolf Basin. Univ. Chicago Press, Chicago, Ill., 613 pp.

Crossley, R., 1984. Controls of sedimentation in the Malawi Rift Valley, Central Africa. Sediment. Geol., 40: 33-50.

Degens, E., Von Herzen, R. and Wong, H. K., 1971. Lake Tanganyika: Water chemistry, sediments, geological structure. Naturwissenschaften, 58: 229-241.

Donovan, R., 1975. Devonian lacustrine limestones at the margin of the Orcadian Basin, Scotland. J. Geol. Scotl., 131: $489-510$.

Dunkleman, T., 1986. The structural and stratigraphic evolution of Lake Turkana. Thesis, Duke Univ., Durham, N.C., 64 pp.

Ebinger, C., Crow, M., Rosendahl, B., Livingstone, D. and Le Fournier, J., 1984. Structural evolution of Lake Malawi, Africa. Nature, 308: 627-629.

Ebinger, C., 1988. Thermal and mechanical development of the East African Rift system. Thesis. Massachusetts Inst. Technol., Cambridge, Mass., 260 pp.

Evert, M. J., 1980. Le Lac Tanganyika, sa faune et la pêche au Burundi. Univ. Burundi Presse, Bujumbura, $200 \mathrm{pp}$.

Frostick, L. E. and Reid, I., 1987. Tectonic control of desert sediments in rift basins ancient and modern. In: L. E. Frostick and I. Reid (Editors), Desert Sediments: Ancient and Modern. Geol. Soc. London, pp. 53-68.

Frostick, L. E., Renaut, R., Reed, I. and Tiercelin, J. J. (Editors), 1986. Sedimentation in the African Rift Systems. Geol. Soc. London Spec. Publ., 25, 382 pp.

Haberyan, K. and Hecky, R., 1987. The Late Pleistocene and Holocene stratigraphy and paleolimnology of Lakes Kivu and Tanganyika. Palaeogeogr., Palaeoclimatol., Palaeoecol., 61: 169-197.

Halfman, J., 1987. High resolution sedimentology and paleoclimatology of Lake Turkana, Kenya. Thesis. Duke Univ., Durham, N.C., 188 pp.

Hecky, R. E., 1978. The Kivu-Tanganyika basin: The last 14,000 years. Pol. Arch. Hydrobiol., 25: 159-165.

Hecky, R. E. and Degens, E. T., 1973. Late PleistoceneHolocene chemical stratigraphy and paleolimnology of the rift valley lakes of Central Africa. Woods Hole Oceanogr. Inst. Tech. Rep., 73-28, 114 pp.

Johnson, T., 1984. Sedimentation in large lakes. Annu. Rev. Earth Planet. Sci., 12: 179-204.

Johnson, T. C., Halfman, J. D., Rosendahl, B. and Lister, 
G., 1987. Climatic and tectonic effects on sedimentation in a rift vally lake: evidence from high-resolution seismic profiles, Lake Turkana, Kenya. Geol. Soc. Am. Bull., 98: 439-447.

LeFournier, J., 1980. Dépôts de préouverture de l'Atlantique Sud. Comparison avec la sédimentation actuelle dans la branche occidentale de rifts Est-Africains. Rech. Geol. Afr., 5: 127-130.

LeFournier, J., Chorowicz, J., Thouin, C., Balzer, F., Chenet, P., Henriet, J., Masson, J., Mondeguer, A., Rosendahl, B., Spy-Anderson, F. and Tiercelin, J. 1985. Le bassin du Lac Tanganyika: Evolution tectonique et sédimentaire. C. R. Acad. Sci. Paris, 301: 1053-1058.

Link, M. and Osborne, R., 1978. Lacustrine facies in the Pliocene Ridge Basin, California. In: A. Matter and M. Tucker (Editors), Modern and Ancient Lake Sediments. Int. Assoc. Sedimentol. Spec. Publ., 2: 167-187.

Livingstone, D., 1965. Sedimentation and the history of water level change in Lake Tanganyika. Limnol. Oceanogr., 10: 607-610.

Mondeguer, A., 1984. La Baie de Burton: approche sédimentologique et structurale. Thesis. Univ. Bretagne Occidentale, Brest $90 \mathrm{pp}$.

Ojeda, H. A., 1982. Structural framework, stratigraphy and evolution of Brazilian marginal basins. Am. Assoc. Pet. Geol. Bull., 66: 732-749.

Owen, R. B., Barthelme, J. W., Renaut, R. and Vincens, A., 1982. Paleolimnology and archaeology of Holocene deposits north-east of Lake Turkana, Kenya. Nature, 298: 523-529.

Reid, I. and Frostick, L., 1985. Beach orientation, bar morphology and the concentration of metalliferous placer deposits: a case study, Lake Turkana, N. Kenya. J. Geol. Soc. London, 142: 837-848.

Robbins, E. I., 1983. Accumulation of fossil fuels and metallic minerals in active and ancient rift lakes. Tectonophysics, 94: 633-658.

Rosendahl, B., 1987. Architecture of continental rifts with special reference to East Africa. Annu. Rev. Earth Planet. Sci., 15: 445 -503.

Rosendahl, B. and Livingstone, D., 1983. Rift lakes of East Africa - new seismic data and implications for future research. Episodes, 1983: 14-19.

Rosendahl, B., Reynolds, D., Lorber, P., Burgess, C., McGill, J., Scott, D., Lambiase, J. and Derksen, S., 1986. Structural expressions of rifting: lessons from Lake Tanganyika, Africa. In: L. Frostick et al. (Editors), Sedimentation in the African Rifts. Geol. Soc. London Spec. Publ., 25: 2943.
Scholz, C. and Rosendahl, B., 1987. Late Pleistocene low lake levels in two African rift lakes. In: Geol. Soc. Am. Natl. Meet. Abstr. with Program, 19: 834.

Schwartz, H., 1981. Lower Pleistocene quiet water ooliths from the Koobi Fora Tuff, East Lake Turkana, N. Kenya. Am. Assoc. Pet. Geol. Bull., 65: 989.

Stow, D. A., 1985. Deep sea clastics: where are we and where are we going? In: P. J. Brenchley and B. P. Williams (Editors), Sedimentology - Recent Developments And Applied Aspects. Geol. Soc. London, pp. 67-93.

Stow, D. A. and Lovell, J., 1979. Contourites: their recognition in modern and ancient sediments. Earth Sci. Rev., 14: 251-291.

Talbot, M., 1984. Late Quaternary sedimentation in tropical African lakes - implications for models of nonmarine oil source bed deposition. In: Symp. Sedimentation in the African Rift Systems, Abstr. programs, Geol. Soc. London.

Tiercelin, J. J., LeFournier, J., Herbin, J. and Richert, J., 1980. Continental rifts: modern sedimentation, tectonic and volcanic control. In: Geodynamic Evolution of the Afro-Arabian Rift System. Acad. Naz. Lincei, Rome, pp. 143-163.

Truckle, P. H., 1976. Geology and late Cainozoic lake sediments of the Suguta Trough, Kenya. Nature, 263: 380-383.

Watkins, R., 1986. Volcano-tectonic control on sedimentation in the Koobi Fora Basin, Lake Turkana. In: L. E. Frostick et al. (Editors), Sedimentation In The African Rifts. Geol. Soc. London Spec. Publ., 25: 85-95.

Winston, D., Woods, M. and Byer, G., 1984. The case for an intracratonic belt - Purcell Basin: Tectonic, stratigraphic and stable isotopic considerations. In: Montana Geol. Society 1984 Field Conf., Northwest. Montana, pp. 103-118.

Wombwell, J. V., 1986. The chemical limnology of Lake Tanganyika. Thesis. Colorado College, Colorado Springs, Colo., 22 pp.

Yuretich, R. F., 1976. Sedimentology, geochemistry and geological significance of modern sediments in Lake Rudolf (Lake Turkana). Thesis. Princeton Univ., Princeton, N.J., 305 pp.

Yuretich, R. F., 1979. Modern sediments and sedimentary processes in Lake Rudolf (Lake Turkana), Kenya. Sedimentology, 26: 313-331.

Yuretich, R. F. and Cerling, T. E., 1983. Hydrogeochemistry of Lake Turkana, Kenya: Mass balance and mineral reactions in an alkaline lake. Geochim. Cosmochim. Acta, 47: 1099-1109. 